\title{
HYDROTHERMAL TREATMENT OF OIL PALM WOOD: EFFECT OF TREATMENT VARIABLES ON DIMENSIONAL STABILITY USING RESPONSE SURFACE METHODOLOGY
}

\author{
MUHAMMAD ANUAR RIDZUAN SALIMAN*; ZAIDON ASHAARI*; EDI SUHAIMI BAKAR*; \\ LEE SENG HUA*; PARIDAH MD TAHIR ${ }^{* *}$; JULIANA ABDUL HALIP** and NABIL FIKRI LEEMON**
}

\begin{abstract}
Oil palm wood (OPW) extracted from felled oil palm trunks during replanting could be a source of replenishment for the depleted timber sources. Nevertheless, dimensional instability of OPW is one of the drawbacks that need to be addressed before it can be utilised efficiently. Therefore, to improve its dimensional stability, hydrothermal treatment using different buffered media was employed in this study and the optimal treatment condition for OPW were investigated. Response surface methodology (RSM) models for treatment temperature, treatment duration and buffered media of hydrothermally treated OPW were developed. OPW samples were hydrothermally treated with different buffered media ( $\mathrm{pH} 4$ to $\mathrm{pH}$ 9), treatment temperature $\left(60^{\circ} \mathrm{C}\right.$ to $160^{\circ} \mathrm{C}$ ) and time (13 min to $\left.147 \mathrm{~min}\right)$. Water absorption (WA) and thickness swelling (TS) of the treated samples were determined. It is demonstrated that hydrothermal treatment has improved the dimensional stability of treated samples with treatment temperature appearing to be the most influential factor. Samples treated in an acidic media displayed lower WA mainly due to the fact that higher amount of hydrophilic hemicellulose was degraded under acidic condition. However, lower TS was observed in the samples treated in alkaline media, probably caused by the removal of lignin that increased the porosity of the OPW.
\end{abstract}

Keywords: buffered media, central composite design, hydrothermal treatment, thickness swelling, water absorption.

Date received: 12 June 2016; Sent for revision: 30 september 2016; Received in final form: 19 December 2016; Accepted: 21 December 2016.

\section{INTRODUCTION}

In 2015, the coverage of oil palm plantations in Malaysia has reached a new high of around $17 \%$ of the total land area covered by oil palm. There are 5.64 million hectares of oil palm plantations in 2015,

Department of Forest Production,

Universiti Putra Malaysia,

43400 UPM Serdang,

Selangor, Malaysia.

E-mail: zaidon@upm edu.my

** Laboratory of Biocomposite Technology,

Institute of Tropical Forestry and Forest Products,

Universiti Putra Malaysia,

43400 UPM Malaysia,

Selangor, Malaysia. an increase of $4.6 \%$ against the 5.39 million hectares recorded in the previous year (MPOB, 2015). Replanting practice at the end of their economic life span has generated a huge amount of biomass. Bakar et al. (2013) reported that an estimated 230$250 \mathrm{~m}^{3}$ of oil palm stems per hectare could be obtained during replanting. Oil palm wood (OPW) extracted from these felled oil palm stems is an ideal substitution for the depleting timber resource. Utilised effectively, alternate wood products derived from OPW could potentially alleviate the deforestation rate in Malaysia which has seen its forested area plummeting from $68.11 \%$ in 1990 to $61.73 \%$ in 2012. Oil palm trunks and fronds have been used for particleboard and slow release fertiliser production (Lee et al., 2015; Nur Nabilah 
et al., 2015). Unfortunately, the poor dimensional stability of OPW as reported by Bakar et al. (2013) has consequently inhibited OPW from being utilised effectively to substitute wood. The main concern of the present study is to improve the dimensional stability of OPW using an effective treatment.

Hydrothermal treatment is one of the effective thermal treatment methods that have been implemented by several researchers (Endo et al., 2016; Tjeerdsma and Millitz, 2005). The efficiency of hydrothermal treatment is highly dependent on treatment temperature and time. Apart from that, the heating media also play an important role. Hydrothermal treatment of beech wood has been conducted in acidic, neutral and alkaline buffered solutions by Talaei and Karimi et al. (2015) and varied mechanical properties were observed in the wood treated using different buffered media. To the authors' knowledge, reports on the influence of hydrothermal treatment using different buffered media on the dimensional stability of OPW are scarce in the literature. Therefore, the present study aimed to improve the dimensional stability of OPW using hydrothermal treatment. Different buffered solutions were used as heating media to investigate the relationship of buffered solutions and dimensional stability. Optimisation models for hydrothermal conditions using response surface methodology (RSM) were also developed in the present work. The current work served as a preliminary study to understand the behaviour of OPW treated in buffered media for potentially further investigation.

\section{MATERIALS AND METHODS}

\section{Materials Preparation}

Twenty-five-year old oil palm (Elaeis guineensis) were harvested at the University Agriculture Park, Universiti Putra Malaysia (UPM), Selangor, Malaysia. The harvested oil palm were then flat sawn into dimensions of $60 \mathrm{~cm} \times 5 \mathrm{~cm} \times 5 \mathrm{~cm}$ in the Forest Research Institute Malaysia (FRIM), Kepong, Selangor, Malaysia. All the samples were stored in cold rooms in UPM at a temperature of $4^{\circ} \mathrm{C}$ to prevent fungal attack and prevent moisture loss.

\section{Response Surface Methodology (RSM) and Central Composite Design}

Central composite design (CCD) using RSM was used in the present study to investigate the effects of treatment variables on the dimensional stability of oil palm wood and bamboo. Three independent variables, namely, buffered media $(\mathrm{pH})$, treatment temperature $\left({ }^{\circ} \mathrm{C}\right)$ and treatment time (min) were selected and the response variable were thickness swelling (TS) and water absorption (WA). The CCD was conducted using Design Expert software (State Ease, Design Expert 9). A 20-run CCD using RSM was developed and the ranges of the variables are shown in Table 1. Each of the independent variable was coded by five different levels as shown in Table 1, where the $\mathrm{pH}$, treatment temperature and treatment times ranged from $4^{\circ} \mathrm{C}$ to $9^{\circ} \mathrm{C}, 60^{\circ} \mathrm{C}$ to $160^{\circ} \mathrm{C}$ and 13 to $147 \mathrm{~min}$, respectively. The experimental conditions of coded and actual values developed using RSM with central composite design are shown in Table 2.

\section{Hydrothermal Treatment Schedule}

Hydrothermal treatment was carried out by boiling the samples in different buffered media ranging from $\mathrm{pH} 4$ to 9 above the atmospheric pressure by using twin digesters. Twenty OPW with dimensions of $60 \mathrm{~cm} \times 5 \mathrm{~cm} \times 5 \mathrm{~cm}$, one for each run, were placed into twin digester. Buffered solution with $\mathrm{pH}$ values ranging from $\mathrm{pH} 4$ to 9 were poured into the twin digester until the samples were fully immersed. Buffered solution was subsequently heated to the required temperature ranging from $60^{\circ} \mathrm{C}-160^{\circ} \mathrm{C}$ as suggested by RSM models. After the respective required treatment times (13 to $147 \mathrm{~min}$ ), the treated samples were removed from the digester and cut into $50 \mathrm{~mm} \times 50 \mathrm{~mm} \times 10 \mathrm{~mm}$ followed by dried in the oven at $103 \pm 2^{\circ} \mathrm{C}$ for $18 \mathrm{hr}$ prior to dimensional stability evaluation.

\section{Dimensional Stability Evaluation}

WA and thickness swelling TS of treated OPW samples were calculated based on $24 \mathrm{hr}$ submersion in distilled water. Five oven-dried samples for each run were immersed in distilled water in a beaker

TABLE 1. THE RANGE AND LEVELS OF THE VARIABLES

\begin{tabular}{|c|c|c|c|c|c|c|c|}
\hline \multirow[t]{2}{*}{ Factor } & \multirow[t]{2}{*}{ Variable } & \multirow[t]{2}{*}{ Units } & \multicolumn{5}{|c|}{$\begin{array}{l}\text { Range and level of } \\
\text { actual and coded values }\end{array}$} \\
\hline & & & $-\alpha$ & -1 & 0 & 1 & $\alpha$ \\
\hline $\mathrm{X}_{1}$ & $\mathrm{pH}$ & - & 4 & 5 & 6.5 & 8 & 9 \\
\hline$X_{2}$ & Temperature & ${ }^{\circ} \mathrm{C}$ & 60 & 80 & 110 & 140 & 160 \\
\hline$X_{3}$ & Time & $\min$ & 13 & 40 & 80 & 120 & 147 \\
\hline
\end{tabular}


TABLE 2. EXPERIMENTAL DESIGN USING CENTRAL COMPOSITE DESIGN

\begin{tabular}{|c|c|c|c|c|c|c|}
\hline \multirow[t]{2}{*}{ Run } & \multicolumn{3}{|c|}{ Coded factor } & \multicolumn{3}{|c|}{ Actual factor } \\
\hline & $X_{1}$ & $X_{2}$ & $X_{3}$ & $\mathrm{pH}$ & $\operatorname{Temp}\left({ }^{\circ} \mathrm{C}\right)$ & Time (min) \\
\hline 1 & -1 & -1 & -1 & 5 & 80 & 40 \\
\hline 2 & 1 & -1 & -1 & 8 & 80 & 40 \\
\hline 3 & -1 & 1 & -1 & 5 & 140 & 40 \\
\hline 4 & 1 & 1 & -1 & 8 & 140 & 40 \\
\hline 5 & -1 & -1 & 1 & 5 & 80 & 120 \\
\hline 6 & 1 & -1 & 1 & 8 & 80 & 120 \\
\hline 7 & -1 & 1 & 1 & 5 & 140 & 120 \\
\hline 8 & 1 & 1 & 1 & 8 & 140 & 120 \\
\hline 9 & $-\alpha$ & 0 & 0 & 4 & 110 & 80 \\
\hline 10 & $\alpha$ & 0 & 0 & 9 & 110 & 80 \\
\hline 11 & 0 & $-\alpha$ & 0 & 6.5 & 60 & 80 \\
\hline 12 & 0 & $\alpha$ & 0 & 6.5 & 160 & 80 \\
\hline 13 & 0 & 0 & $-\alpha$ & 6.5 & 110 & 13 \\
\hline 14 & 0 & 0 & $\alpha$ & 6.5 & 110 & 147 \\
\hline 15 & 0 & 0 & 0 & 6.5 & 110 & 80 \\
\hline 16 & 0 & 0 & 0 & 6.5 & 110 & 80 \\
\hline 17 & 0 & 0 & 0 & 6.5 & 110 & 80 \\
\hline 18 & 0 & 0 & 0 & 6.5 & 110 & 80 \\
\hline 19 & 0 & 0 & 0 & 6.5 & 110 & 80 \\
\hline 20 & 0 & 0 & 0 & 6.5 & 110 & 80 \\
\hline
\end{tabular}

and placed in a vacuum apparatus for $15 \mathrm{~min}$ evacuation. After evacuation, the samples were left immersed in the water at atmospheric pressure for $24 \mathrm{hr}$. The weights and thickness before and after the soaking process were determined.

\section{RESULTS AND DISCUSSION}

\section{Regression and Adequacy of the Model}

From the experimental result, two linear equations were obtained. The final equations in terms of actual factors are shown below:

$\mathrm{WA}=18.30+0.44 \mathrm{pH}+0.14$ Temperature +0.03 Time

$\mathrm{TS}=6.38-0.08 \mathrm{pH}-0.02$ Temperature -0.004 Time

To ensure the fitted model gave a sufficient approximation of the results obtained in the experimental conditions, the adequacy of the model was evaluated. Insignificant lack-of-fit values of 0.8152 and 0.6296 for WA and TS, respectively, suggested that the model was statistically appropriate for further investigation. The fit of the model was evaluated using coefficient of multiple regression $\left(r^{2}\right)$ and adjusted $r^{2}$ was used for confirmation of the model adequacy. Based on the analysis, $\mathrm{r}^{2}$ values of 0.9333 and 0.9005 for the WA and TS, respectively, indicated high fitness of the model. The adequacy of the model was further proved by high adjusted $r^{2}$ of 0.9208 and 0.8818 , respectively.

\section{Effects of Hydrothermal Treatment on Dimensional Stability of the Samples}

The effects of variables $(\mathrm{pH}$, treatment temperature and time) on the response of WA and TS of the hydrothermally treated samples are presented in Figures 1 and 2. When the OPW samples were treated at $160^{\circ} \mathrm{C}$ for $80 \mathrm{~min}$, the lowest TS of $2.59 \%$ were obtained. On the contrary, the highest TS of $4.60 \%$ was recorded with the samples treated at $60^{\circ} \mathrm{C}$ for $80 \mathrm{~min}$. Lower TS could be obtained when treating the samples at higher temperature even when shorter time was used. For example, OPW samples treated at $140^{\circ} \mathrm{C}$ for 40 min resulted in a TS of $2.76 \%$, which was slightly lower than the TS of OPW samples $(2.87 \%)$ that subjected to lower temperature but longer time $\left(110^{\circ} \mathrm{C}\right.$ for $\left.147 \mathrm{~min}\right)$. From the given example, it could be seen that treatment temperature is a more influential factor than that of treatment time. The findings suggested that 107 min of treatment time could be cut off when the treatment temperature was raised by $30^{\circ} \mathrm{C}$. The WA pattern mirrored that of TS as lower WA obtained when subjected to higher treatment temperature. The obtained results were comparable to the findings reported by other researchers who treated OPW with different methods. Maminski et al. (2016) impregnated OPW with 1,3-dimethylol-4,5-dihydroxyethyleneurea and found that the TS and WA of the treated OPW was $1.3 \%-2.5 \%$ and $19 \%-27 \%$, respectively. Another modification method called furfurylation was carried out by Szymona et al. (2014) on OPW and the TS values of $1.1 \%-1.4 \%$ and WA values of $30 \%-45 \%$ were recorded. Destruction of several hydroxyl groups has reduced the affinity of the wood to water and therefore led to improvement in dimensional stability (Weiland and Guyonnet, 2003). The inaccessibility of the hydroxyl group to water molecules due to the increase of cellulose crystallinity during heat treatment has also imparted better stability in dimension to the treated wood (Boonstra and Tjeerdsma, 2006).

On the other hand, the $\mathrm{pH}$ values of the heating media exerted influence when both treatment temperature and time remained constant. Treated at the same level of treatment temperature and time, samples treated in the alkaline media $(\mathrm{pH}>6.5)$ displayed better TS compared to samples treated in an acidic media. The findings were in agreement with Ebadi et al. (2015) who reported that the highest anti-swelling efficiency (ASE) was attained in the samples treated in a buffered media with $\mathrm{pH}$ of 8 . Nevertheless, contrary observation for WA was obtained as higher WA was found in the samples treated using alkaline media. Formic and acetic acids are formed during heat treatment and these released 
(a)

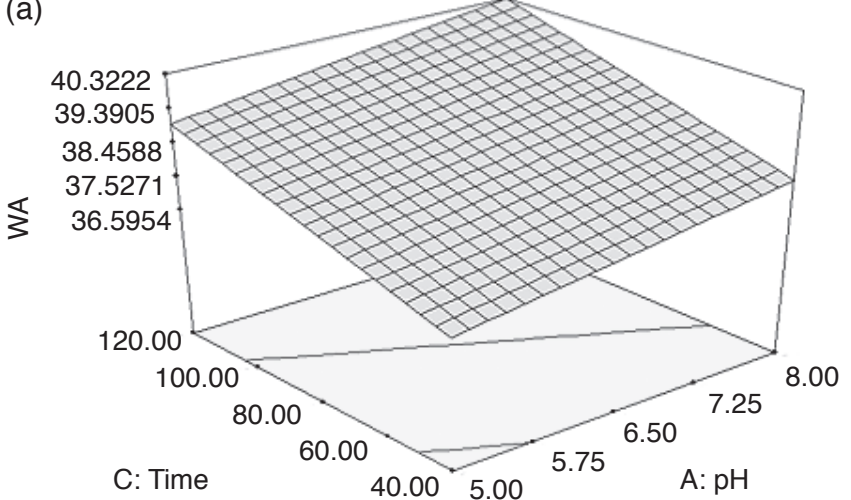

(b)

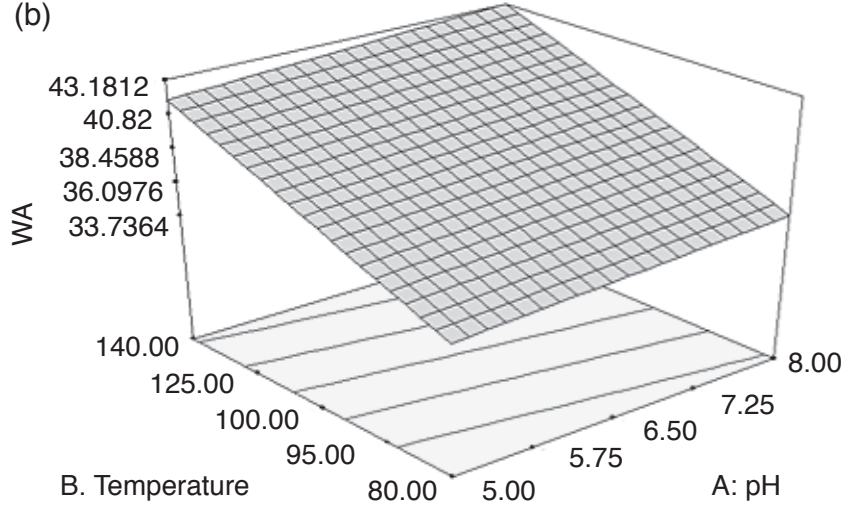

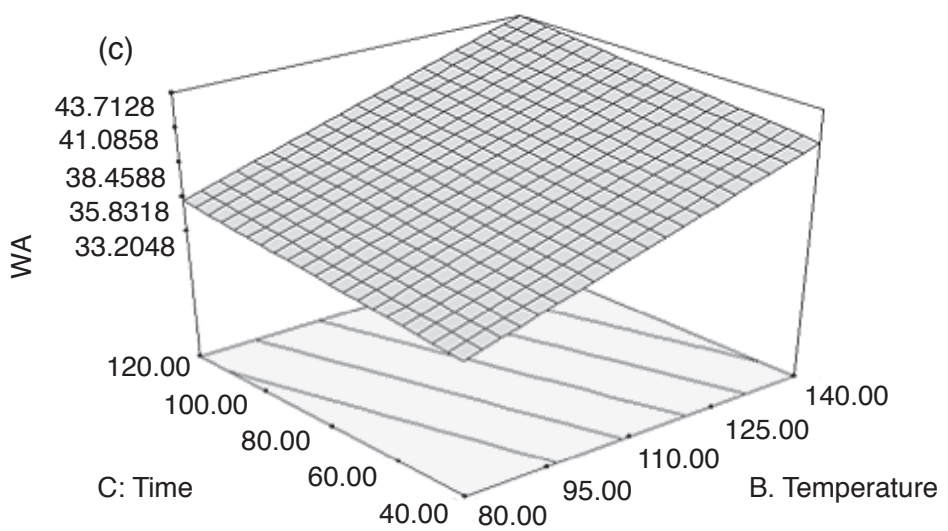

Figure 1. The 3D-surface plots of water absorption (WA) as function of (a) time and $p H,(b)$ temperature and $p H$ and (c) time and temperature.

(a)

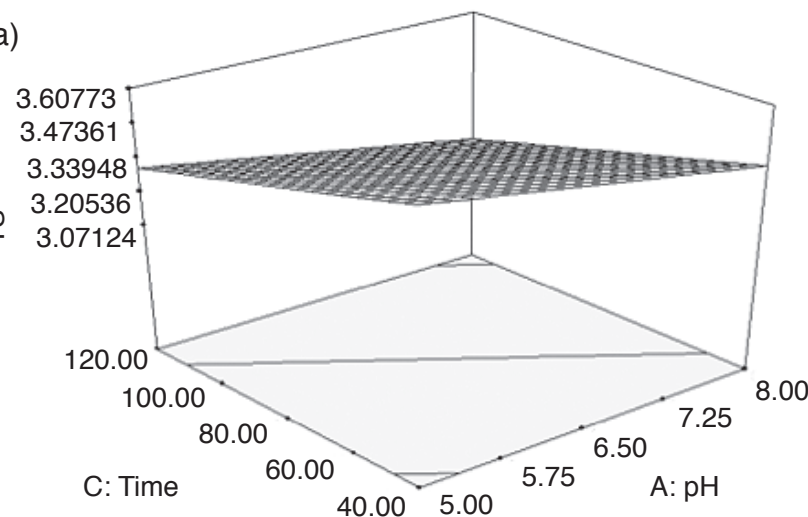

(b)

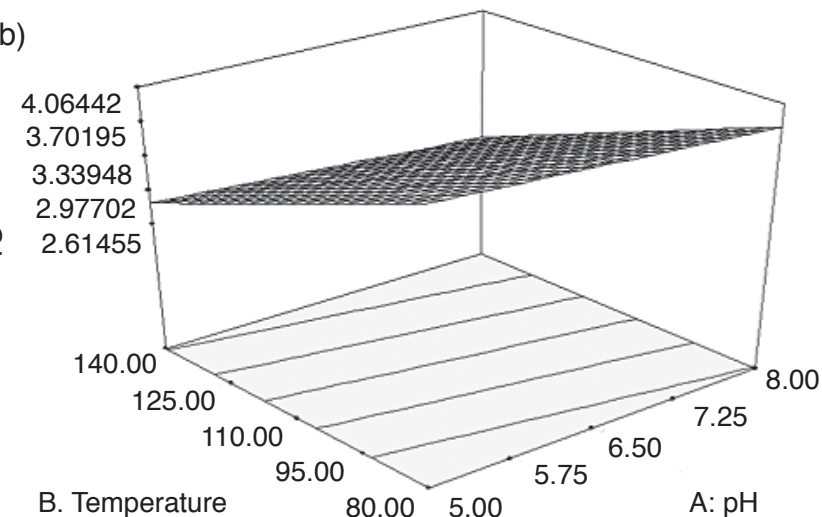

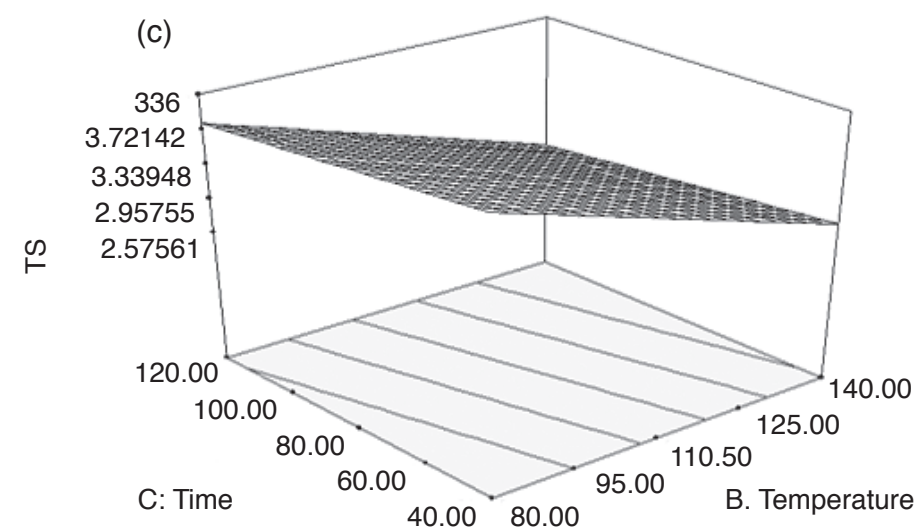

Figure 2. The 3D-surface plots of thickness swelling (TS) as function of (a) time and $p H,(b)$ temperature and $p H$ and (c) time and temperature. 
acids are responsible for the degradation of the carbohydrates of wood, especially hemicellulose (Tjeerdsma et al., 1998). Therefore, a higher amount of hemicellulose was removed under acidic condition where the degradation is more severe. However, alkaline hydrolysis was found to be able to remove lignin from the wood. Hence, the removal of hemicellulose together with lignin in alkaline media accounted for a higher loss of wood constituents and may have rendered higher porosity to OPW. Therefore, a higher amount of water was able to be retained within the wood and led to higher WA. Consequently, ensuing swelling was partially extended into the existing voids and this led to a lower swelling of thickness.

Apart from improved dimensional stability, hydrothermal treatment altered the chemical composition in the wood considerably. This alteration could have in turn bestowed several advantageous attributes to the treated OPW, for example, resistance to termites. Hemicellulose, cellulose and lignin compose the woody cell wall. Being the less thermally stable constituent, hemicellulose degrades first during hydrothermal treatment followed by cellulose and lignin (Kamdem et al., 2002). Termites rely on the celluloses derived from wood as their food source. The degradation of carbohydrate during hydrothermal treatment inflicted great loss of favourable food sources for termites and hence, partially prevented OPW from being attacked by termites. Furthermore, the resultant reduction in hygroscopicity of OPW by hydrothermal treatment might be deemed to be another reason that enhance its resistance against termites. Subterranean termites, the most aggressive termite species responsible for $95 \%$ of termite damage in Malaysia, require high amounts of moisture to survive and are therefore attracted to wood with a high moisture content. Hydrothermal treatment could reduce the equilibrium moisture content (EMC) of OPW by decreasing the accessibility of the hydroxyl groups in hemicellulose to water. In addition, the formation of less hygroscopic furfural polymer from the hydrolysis of hemicellulose under high temperature has also contributed to the reduction of EMC in wood (Tjeerdsma and Militz, 2005). Consequently, lower wood moisture content could repulse the invasion of termites and confer better termite resistance to the OPW.

\section{CONCLUSION}

Based on the findings, it can be concluded that the dimensional stability of oil palm wood was enhanced by hydrothermal treatment implemented in the present work. The following are the summary of conclusions according to the presented study:

1. RSM models suggested that the treatment temperature influence both TS and WA of the OPW to a great extent as the dimensional stability improved along with increasing temperature.

2. Treatment time is a less crucial factor in the dimensional improvement of OPW compared to treatment temperature. Better dimensional stability could be observed in the samples treated at higher temperature even when exposed to a shorter time.

3. The $\mathrm{pH}$ value of the buffered media also exerted significant influence as hydrothermal treatment conducted in alkaline media resulted in lower TS but higher WA. Removal of lignin in alkaline media needs to be further investigated and studied for better understanding to its influence on the dimensional stability of treated OPW.

4. Apart from that, hydrothermal treatment could have conferred better biological durability to $\mathrm{OPW}$ which is worth investigating in future studies.

\section{REFERENCES}

BAKAR, E S; TAHIR, P M; SAHRI, M H; MOHD NOOR, M S and ZULKIFLI, F (2013). Properties of resin impregnated oil palm wood (Elaeis guineensis Jacq.). Pertanika J. Tropical Agricultural Science, 36(S): 93-100. http: / / www.pertanika.upm.edu.my/Pertanika \%20 PAPERS/JTAS\%20Vol.\%2036\%20(S)\%20 Dec. $\% 202013 / 09 \% 20$ Page $\% 2093-100 \%$ 20(JTAS $\% 20$ 0464-2012).pdf

BOONSTRA, M J and TJEERDSMA, B (2006). Chemical analysis of heat treated softwoods. Holz als Roh- und Werkstoff, 64(3): 204-211. http:/ / link. springer.com/article/10.1007\%2Fs00107-005-0078-4

EBADI, S E; KARIMI, A; CHOO, A C Y; ASHAARI, Z; NAJI, H R; SOLTANI, $M$ and RIDZUAN, S M A (2015). Physical behavior of hydro-thermally treated oil palm wood in different buffered $\mathrm{pH}$ media. BioResources, 10(3): 5317-5329. http://ojs. cnr.ncsu.edu / index.php / BioRes / article / view / BioRes_10_3_5317_Ebadi_Hydro_Thermal_Oil_ Palm_Media

ENDO, K; OBATAYA, E; ZANIYA, N and MATSUO, $M$ (2016). Effects of heating humidity on the physical properties of hydrothermally treated spruce wood. Wood Science and Technology. DOI 10.1007/s00226016-0822-4. http://link.springer.com/article/10.10 07\%2Fs00226-016-0822-4.

KAMDEM, D P; PIZZI, A and JERMANNAUD, A (2002). Durability of heat-treated wood. Holz als 
Roh- und Werkstoff, 60(1): 1-6. http: / / link.springer. com / article / 10.1007 / s00107-001-0261-1

LEE, S H; ZAIDON, A; LUM, W C; H'NG, P S; TAN, L P; CHOW, M J; CHAI, E W and CHIN, K L (2015). Properties of particleboard with oil palm trunk as core layer in comparison to three-layer rubberwood particleboard.J.Oil Palm Res. Vol.27(1):67-74.http: / / jopr.mpob.gov.my / properties-of-particleboardwith-oil-palm-trunk-as-core-layer-in-comparisonto-three-layer-rubberwood-particleboard / ?v=true

MALAYSIA PALM OIL BOARD (MPOB) (2015). Oil palm planted area by state as at December 2015 (hectares). http:/ / bepi.mpob.gov.my/images / area/2015 / Area_summary.pdf, accessed on 10 June 2016.

MAMINSKI, M; KOZAKIEWICZ, P; JASKOLOWSKI, W; CHIN, K L; H'NG, P S and TOCZYŁOWSKA-MAMINSKA, R (2016). Enhancement of technical value of oil palm (Elaeis guineensis Jacq.) waste trunk through modification with 1,3-dimethylol-4,5-dihydroxyethyleneurea (DMDHEU). European J. Wood and Wood Products, 74 (6): 837-844. http://link.springer.com/ article/10.1007 / s00107-016-1086-2

NUR NABILAH, A K; ZAIDON, A; AHMAD HUSNI, M H; AZMY, M and LEE, S H (2015). Treatability of oil palm frond and rubber wood chips with urea for the development of slow release fertilizer. J. Oil Palm Res. Vol. 27(3): 220-225. http: / /jopr.mpob.gov.my/ treatability-of-oil-palmfrond-and-rubber-wood-chips-with-urea-for-thedevelopment-of-slow-release-fertiliser-2/ ?v=true
SZYMONA, K; BORYSIUK, P; H’NG, P S; CHIN, K L and MAMINSKI, M (2014). Valorization of waste oil palm (Elaeis guineensis Jacq.) biomass through furfurylation. Materials and Design, 53: 425-429. http: / / www.sciencedirect.com / science / article / pii/S0261306913006560

TALAEI, A and KARIMI, A (2015). Compression strength, hardness and shear strength of heat treated beech (Fagus orientalis) wood in buffered mediums. Proc. of the $24^{\text {th }}$ IIER International Conference. Barcelona, Spain, 8 - 10 May 2015. http://www. worldresearchlibrary.org/up_proc/pdf / 28143056447217-20.pdf

TJEERDSMA, B F and MILITZ, H (2005). Chemical changes in hydrothermal treated wood: FTIR analysis of combined hydrothermal and dry heattreated wood. Holz als Roh- und Werkstoff, 63(2): 102-111. http: / / link.springer.com/article/10.1007 \%2Fs00107-004-0532-8

TJEERDSMA, B F; BOONSTRA, M; PIZZI, A; TEKLEY, P and MILITZ, H (1998). Characterization of thermally modified wood: molecular reasons for wood performance improvement. Holz als Roh- und Werkstoff, 56 (3): 149-153. http: / / link.springer.com/ article/10.1007\%2Fs001070050287

WEILAND, J and GUYONNET, R (2003). Study of chemical modifications and fungi degradation of thermally modified wood using DRIFT spectroscopy. Holz als Roh- und Werkstoff, 61(3): 216-220. http:/ / link.springer.com / article / 10.1007\%2Fs00107-0030364-y 